\title{
Organization and Product Design Pairings: A Review of Product Innovation Capabilities, Conceptualization and Future Directions
}

Oluwasoye P. Mafimisebi, Demola Obembe, and Oluwakayode Aluko

\section{Forthcoming in Strategic Change.}

Cite as: Mafimisebi, O. P., Obembe, D., \& Aluko, O. (2019). Organisation and product design pairings: A review of product innovation capabilities, conceptualization and future directions. Strategic Change, 1-41

Please note that final version may slightly differ.

Leicester Castle Business School, De Montfort University, Leicester.

Correspondence: Oluwasoye P. Mafimisebi, Department of Strategic Management and Marketing, Leicester Castle Business School, De Montfort University, Leicester, LE1 9BH, United Kingdom. Email: Oluwasoye.mafimisebi@dmu.ac.uk 


\title{
Organization and Product Design Pairings: A Review of Product Innovation Capabilities, Conceptualization and Future Directions
}

\begin{abstract}
Drawing on the Resource-based view of firms and market orientation theory, this paper presents a complementary view of the influence of product innovation capabilities (PICs) on organization and product design pairings. By exploring the influence of three complementary factors; market orientation, organizational form, and managerial strategic decisions, as essential determinants for emergence of architectural pairings, we theorize that PICs lead to better; organization and product design pairings selection, unique customer benefits, market acceptance, significant cost reductions, and new products development, and consequently superior organizational performance. We propose in essence, that PICs significantly shape and determine the success of architectural pairings between organization and product designs, and act as a source of sustainable competitive advantage for organizations. We further identify scope for future research to evaluate measures and validity of product innovation capability dimensions, and the extent of influence of the identified factors on architectural pairings.
\end{abstract}

\section{INTRODUCTION}

Organizations face particularly increased difficulties in gaining sustained competitive advantage when adopting a mirroring approach to organization and product design pairings (Brusoni, Prencipe, \& Pavitt, 2001; Cabigiosu \& Camuffo, 2010; Campagnolo \& Camuffo, 2010; Furlan, Cabigiosu, \& Camuffo, 2014; Colfer \& Baldwin, 2016; MacCormack, Baldwin, \& Rusnak, 2012; Querbes \& Frenken, 2018). While research suggests that simultaneous 
mirroring and misting may occur depending on a number of contextual product characteristics (Burton \& Galvin, 2018) and partial mirroring yields the most effective performance outcomes (Pil \& Cohen, 2006; Park \& Ro, 2013), we know little about how product innovation capabilities (PICs) influence architectural pairings between organization and product designs.

The similarity between product architecture and organization design has become known as the "mirroring hypothesis" (Querbes \& Frenken, 2018). Product architecture is generally described as the scheme by which the functions the product performs are allocated to its constituent components (Ulrich, 1995). A variety of studies have emphasized the vital role of architecture in the successful development of a firm's new products, the competitiveness of its product portfolio and the evolution of its organizational capabilities (e.g., Baldwin \& Clark, 2000; Sanchez \& Mahoney, 1996; Schilling, 2000; Ulrich, 1995). More so, extant literature has studied the link between product architecture and characteristics of organizations that develop the product (Sosa, Eppinger, \& Rowles, 2004; Cataldo, Wagstrom, Herbsleb, \& Carley, 2006).

The centrality of the mirroring hypothesis to 'products design organizations' perspective is further challenged by increased turbulence in the world of business (Burton \& Galvin, 2018; Colfer \& Baldwin, 2016; Mafimisebi \& Nkwunonwo, 2015). If markets are perpetually shifting, how can an organization determine which architectural pairings will succeed, for instance? Moreover, managers will find it difficult to establish appropriate strategic goals for firms if they cannot distinguish which activities their firm should commit to and which to avoid (Pil \& Cohen, 2006). Thus, we propose that product innovation capability is an essential factor in distinguishing which organization and product design pairings will succeed, and influence such architectural pairings. Further, firms engaged in product innovation can simultaneously or separately commercialize a new product, elaborate new architectural pairings, and sustained advantage (cf. Atuahene-Gima \& Ko, 2001; Cohen \& Klepper, 1996; Fritsch \& Meschede, 2001; Park \& Ro, 2013). 
Product innovation is defined as the commercialization of new goods or services to meet an external user need (Damanpour, 2010). Though the competitive advantage gained from organization and product design pairings may be temporal (Burton \& Galvin, 2018; Cataldo et al., 2006; Sosa et al., 2004), our contention is that PICs can extend and sustained such advantage. Moreover, in order to innovate, organizations must search for new knowledge or for ways to recombine existing knowledge in novel ways (Grant, 1996; Laursen \& Salter, 2006; Leiponen \& Helfat, 2010; Li et al., 2013; Snihur \& Wiklund, 2018). This typically entails broad search in different contexts and industries (Katila \& Ahuja, 2002; Snihur \& Wiklund, 2018), for instance, an Indian Eye Care firm who developed a new business model for running a hospital specialised in cataract surgery based on McDonald's mode of operation (Martins, Rindova, \& Greenbaum, 2015). Even so, a significant amount of studies found that established firms predominantly search locally; that is, close to their existing knowledge base rather than broadly due to high costs of searching in unfamiliar territories (Laursen, 2012; Patel \& Pavitt, 1997; Stuart \& Podolny, 1996).

We conceptualize PICs as involving novel undertakings in terms of internal and external search for new knowledge or for ways to recombine existing knowledge in exceptional ways to produce new products (or services) that deliver customer value. Product innovation is often aimed at maintaining the sustenance of product life because products are by their nature susceptible to dramatic change as a result of unconventional market demands, consumers' preference and needs, technological change, shorter product life cycle, and increased competition. The extant studies suggest that product innovation is very crucial because it allow organizations to respond quickly to customers' needs, increase product quality and variety, and gain market share (Fritsch \& Meschede, 2001; Kuncoro \& Suriani, 2018; Nieto \& Santamaria, 2010; Panigraphy \& Pradhan, 2015; Vaona \& Pianta, 2008). Furthermore, organizations increase their profit margins because customers are willing to pay more for new and improved 
products; and organizations earn monopoly rents until competitors are able to imitate the new products (Cohen \& Klepper, 1996; Fossas-Olalla, Minguela-Rata, Lopez-Sanchez, \& Fernandez-Menendez, 2015; Fritsch \& Meschede, 2001). Still, companies with robust and heterogenous PICs would make it difficult for rivals to imitate their products thereby gaining sustainable competitive advantages (Arslanagic-Kalajdzic, Balboni, Maglajlic, \& Bortoluzzi, 2017; Hsiao \& Hsu, 2018; Woschke \& Haase, 2016).

Drawing on the Resource-based view (RBV) of firm, our argument is that innovation is a key element in competitive differentiation and crucial for the sustainable growth of firms; it can dynamically boost the profitability of firms' products. For example, an upgraded computer software that calculates more rapidly or synchronizes data better can help an IT firm to attract more users, gain larger market share, and harvest higher profits ( $\mathrm{Li} \& \mathrm{Ni}, 2018)$. The upgrading of the software can be perceived as product innovation because it is associated with the aim of making the product better (Saha, 2007). In context, product innovation as an activity, aims to improve the cumulative product quality and make better products (Lambertini \& Mantovani, 2009; Pan \& Li, 2016). Also, organization dynamics capabilities can increase value chain innovation (Hansen \& Birkinshaw, 2007). In this paper, our aim is to review the research evidence surrounding how PICs influence organization and product design pairings. On the one hand, product innovation leads to increase market share, enhancing the sustained market performance of an organization. On the other hand, PICs allows for better architectural pairings success and impact on industry surplus sharing of a firm.

We propose that, under certain conditions, product innovation capability advantages allow firms to gauge which architectural pairings prosper and consequently establish how industry surplus is divided. In particular, we argue that because firm-specific advantages are perceived as a two-dimensional construct, when combined with product innovation capability, it should have different influences on architectural pairings between organization and product 
design (Brusoni \& Prencipe, 2001; Hsiao \& Hsu, 2018; MacCormack et al., 2012; Querbes \& Frenken, 2018). This can be examined from dynamic capability perspective but also broadly linked to the resource-based view of firms. Following Branzei \& Vertinsky (2006), we start by defining product innovation capability in terms of (1) the capability life-cycle stage - whether capabilities emerge and develop from scratch or whether extant capabilities are crosspollinated, updated, and adjusted; and (2) the capability payoff schedule - the time lag required before operational capabilities can translate into firm-level performance improvements. As Atuahene-Gima (2005) explains, managers face an important strategic dilemma in product innovation: how to exploit existing product innovation competencies (competence exploitation) while avoiding their dysfunctional rigidity effects by renewing and replacing them with entirely new competencies (competence exploration). Therefore, we further propose that the influence of PICs on architectural pairings between organization and product design are evident in firms' market orientation, organizational form, and managerial strategic decisions that augment the architectural pairing advantages associated with 'organizations design products'.

Upon conducting a search of the extant literature, we found a lack of theoretical attention being paid to understanding the influence of PICs on organization and product design pairings (Querbes \& Frenken, 2018). The vast majority of the research studies on organization and product pairings have focused more on investigating modularity and mirroring hypothesis (Brusoni \& Prencipe, 2001; Burton \& Galvin, 2018; Colfer \& Baldwin, 2016; MacCormack et al., 2012; Park \& Ro, 2013; Pil \& Cohen, 2006). These studies also enrich our understanding of interdependence within modules and independence between modules (Ulrich, 1995), and organizations design products. Albeit several definitions of modularity exist, however in this context, we use it to denote the way that a product's architecture is decomposed into different parts or modules (MacCormack et al., 2012). 
A significant insight that emerged from extant literature on mirroring hypothesis holds that organizational design is expected to mirror its product's design (Colfer \& Baldwin, 2016; MacCormack et al., 2012). However, Querbes \& Frenken (2018) found that the mirroring hypothesis in new product development itself has rarely been tested, leaving our understanding of the complementary influence of PICs on organization and product design pairings insufficient. Hence, this article presents a complementarity picture of organization and product design pairings in the context of product innovation capability. In particular, we draw insights from product innovation and dynamic capability studies to complement existing research on organization and product design pairings.

Our review advances the notion that 'organizations design products' invokes the prospect that PICs influence architectural pairings between organization and product design. Given this potential, we theorize that PICs lead to better selection of organization and product design pairings, unmatched customer benefits, better market acceptance, substantial cost reductions, and firm's ability to create new products, any of which should lead to superior organizational performance (Atuahene-Gima \& Ko, 2001; Li, Zhao, Tan, \& Liu, 2008; Slater \& Narver, 1995; Slater, Mohr, \& Sengupta, 2014). We thus explain product innovation in the context of prior studies relevant to understanding its influence on organization and product design pairings. Next, we conceptualize PICs influence on organization and product designs across three different themes: market orientation, organizational form, and managerial strategic decisions. Finally, we discuss the contributions, limitations and future directions for research and practice.

\section{UNDERSTANDING PRODUCT INNOVATION}

Innovation implies the generation and implementation of new ideas, processes or products. Product innovation, in the broadest sense, has received significant attention over the 
recent decades. In context, product innovation is a broad concept that encompasses a substantial number of distinct dimensions, discussed in the literature by Adams, Bessant, \& Phelps (2006), Belenzona \& Patacconi (2013), Brown \& Eisenhardt (1995), Dewangan \& Godse (2014), Prange \& Schlegelmilch (2018), Schaefer (1999), and Shibata (2009). Specific examples of product innovation dimensions include percentage of ideas found viable for commercialization (Dewangan \& Godse, 2014), precise, stable and early product definition before development begins (Cooper, 1999), synergy potential and/or dependency on other products (Griffin \& Page, 1993; Astebro \& Michaela, 2005), product innovation portfolio balance (Adams et al., 2006; Kindstrom, Kowalkowski, \& Sandberg, 2013), newness to organization and novelty of product (Cooper, 1981; Duhamel \& Santi, 2012), and future duration of product (Astebro \& Michaela, 2005).

Product innovation is crucial for organizations in developing and maintaining their competitive advantage (Chen, 2007), and growing competition and accelerating product life cycles mean that product innovation becomes even more significant (Slater, Mohr, \& Sengupta, 2014). The successful introduction of new products is perceived as the lifeblood of most organizations (Alegre \& Chiva, 2008; Balachandra \& Friar, 1997; Prange \& Schlegelmilch, 2018; Shibata, 2009; Slater et al., 2014). In fact, a Boston Consulting Group Senior Executive Innovation Survey (Andrew et al., 2010) found that product innovation was among the top three strategic priorities for $71 \%$ of companies and that $70 \%$ of companies considered new-tothe-world products as "important" or "very important" to the company's future. For Gault (2018, p. 619) product innovation is defined as "a product, made available to potential users, that is new or significantly changed with respect to its characteristics or intended uses."

As yet, there is no common definition of product innovation in the extant literature, which makes it difficult to define the borders of the research topics and to compare their results across studies. This has been partly attributed to the fact that product innovation is the most 
popular innovation type (Edwards-Schachter, 2018). Following Damanpour (2010), we define product innovation as the commercialization of new goods or services to meet an external user need. This perspective implies that product innovation is innovative outputs (goods, services, technologies) that have been introduced to the market (Branzei \& Vertinsky, 2006). It includes products that are new to the firms and significant enhancements or improvements for existing products but exclude minor modifications and/or purely aesthetic changes. Organizations aiming to master the intricacies of product innovation and identify which product architectural pairings will succeed in turbulent market must address that wide arrays of product innovation dimensions. Clearly, product innovation is a multi-dimensional, organization-wide challenge to the managers charged with the tasks of organization and product design pairings.

Moreover, if implemented successfully, product innovation allows firms to respond quickly to customers' needs, increase product quality and variety, and gain market share (Fossas-Olalla et al., 2015; Fritsch \& Meschede, 2001; Nieto \& Santamaria, 2010; Vaona \& Pianta, 2008). Furthermore, organizations increase their profit margins because buyers are willing to pay more for new products; and organizations earn monopoly rents until competitors manage to imitate the new products (Cohen \& Kleper, 1996; Fritsch \& Meschede, 2001). At present, the general trend is the application of new ideas to products that increase their economics and/or social value (at the core of the "value proposition" of firms). This process is usually interactive and involves a diversity of actors and settings - for example, developed in the context of firms but also other organizations from the public or civil sectors such as the case of a public spin-off, a social enterprise, or a social start-up (Edwards-Schachter, 2018).

In the last decade, however, the seminal work of Von Hippel (2005) on democratizing innovation shifted attention from inside to firms' external actors, affirming that users of products and services - both firms and individual consumers - are increasingly able to innovate for themselves. This work emphasizes the existence of great advantages of user-centred and 
user-led product innovation processes over the manufacturer-centric product innovation systems applied for several decades. This view can be extended to the organization and product design pairings decision. In turn, as we propose, firms would be able to obtain comprehensive view of which architectural pairings are likely to prosper and shape how surplus is divided in an industry. In a dynamic and turbulent environment, the key to product innovation for organizations is integrating organizational capabilities (Xie, Fang, Zeng, \& Huo, 2016). This view also enables the categorization of organizational capabilities into operational or dynamics. In perspective, operational capabilities include the means and practices of efficiently configuring existing resources into products and services, whereas dynamic capabilities reflect the explorative side of the organization (Eisenhardt \& Martin, 2000; Teece, 2007; Winter, 2000; 2003; Zahra, Sapienza, \& Davidsson, 2006).

There are different viewpoints on the definition and components of dynamic capability. Thus, we define dynamic capability as “firm's ability to integrate, build and reconfigure internal and external competences" (Teece, Pisano, \& Shuen, 1997:516) or as the "firm's behavioural orientation constantly to integrate, reconfigure, renew and recreate its resources and capabilities and upgrade and reconstruct its core capabilities" (Wang \& Ahmed, 2007:35). In this context, dynamic capabilities are processes to improve the organization and product design pairings of a firm (Barreto, 2010; Querbes \& Frenken, 2018) that transfer the firm's architectural pairings into distinct products that deliver the greatest value at the least cost (Hsiao \& Hsu, 2018; Shibata, 2009; MacCormack et al., 2012). It is essential to acknowledge that dynamic capabilities are not resources for themselves (Ambrosini \& Bowman, 2009) but vital to the strategic selection and positioning of organization and product design pairings.

According to Feiler \& Teece (2014) dynamic capabilities involve the effective orchestration of a cluster of activities directed toward achieving something that is strategically imperative. We extend this perspective to organization and product design pairings decision as 
strategically imperative which involve different clusters of activities. Previous research has categorised dynamics capabilities into three clusters of activities and adjustments. Teece (2007) maintained that dynamic capability of a firm could be disaggregated into the capacity to; sense and shape opportunities and threats (sensing capability), seize opportunities (seizing capability), and maintain competitiveness through enhancing, combining, protecting, and reconfiguring the organization's intangible and tangible assets (reconfiguring capability). In addition, empirical studies found that dynamic capability components also extend to absorptive capacity (Cheng \& Chen, 2013; Hertog, Aa, \& Jong, 2010; Wang \& Ahmed, 2007), integrative capability (Kogut \& Zander, 1992; Teece, 2007; Winter, 2003; Wu, He, Duan, \& O’Regan, 2012), relational capability (Barreto, 2010; Helfat et al., 2007), and product innovation capability (Branzei \& Vertinsky, 2006; Danneels, 2002) PICs are acknowledged as one of the most important dynamic capabilities (Helfat, 1997). Wu et al. (2012) further show that dynamic capabilities facilitate firms' strategic changes toward sustainability and higher competitive advantage through searching, prioritizing, positioning, planning, modifying, and leveraging.

We found that a significant number of studies emphasize the relationship between dynamic capabilities and product innovation throughout the process, and argue that a firm's dynamic capabilities could substantially enhance its ability to innovate and by extension organization and product design pairings decision (Cataldo et al., 2006; Lin, Su, \& Higgins, 2016; Sosa et al., 2004; Woschke \& Haase, 2016; Wang \& Ahmed, 2007). The main premise is that while a firm's operational capabilities are involved directly in the product innovation process by converting inputs into outputs, dynamic capabilities influence this process by updating, integrating and reconfiguring a firm's architectural pairings (Helfat el., 2007; Helfat \& Peteraf, 2003; Helfat \& Winter, 2011). This specifically shapes architectural pairings innovation in which case firms are able to dexterously integrate and reconfigure organization 
and product design pairings to gain sustained competitive advantage (Henderson \& Clark, 1990; Wang \& Ahmed, 2007).

Accordingly, we present the notion of dynamic capabilities in context of organization and product design pairings decision since there is a broad consensus among scholars that they are preconditions of new product developments (Breznik \& Hisrich, 2014; Rothaermel \& Hess, 2007; Teece, 2007; Woschke \& Haase, 2016). However, we argue that it is essential to make a distinction between innovation capability and product innovation capability. In our article, we define innovation capability as "the ability to continuously transform knowledge and ideas into new products, processes, and systems for the benefit of the firm and its stakeholders" (Lawson \& Samson, 2001, p. 394). By contrast, product innovation capability refers to the firm's capacity of developing and adapting new products in order to satisfy market needs (Adler \& Shenbar, 1990). This definition, when incorporated into organization and product design pairings context, implies that it is firm's capacity to develop and adapt in the constant changing market that determine which architectural pairings prosper. Likewise, product innovation capability represents a socially complex and imperfectly imitable organizational capability that generates competitive advantage and better performance (Arslanagic-Kalajdzic et al., 2017; Tsai \& Yang, 2013; Vicente, Abrantes, \& Teixeira, 2015). In the next section, we conceptualize PICs and explore its influence on organization and product design parings.

\section{CONCEPTUALIZING PRODUCT INNOVATION CAPABILITIES}

Balancing organization and product design pairings has become increasingly important for organizations facing competitive, regulatory, consumers and community pressures. Although the significance of product innovation has been discussed in the literature, as well as in business forums, conceptualization of PICs is inconclusive. This may be due to different viewpoints on PICs ranging from modularity, innovation management and strategic 
management to general management perspectives. Notwithstanding, dynamic capabilities for successful product innovation encompass firms' abilities to acquire and assimilate external knowledge, transform it into novel, unique competencies and ideas, and then harvest these ideas by first generating and afterward effectively commercializing new or improved products (Adams et al., 2006; Branzei \& Vertinsky, 2006; Edwards-Schachter, 2018; Kindstrom, Kowalkowski, \& Sandberg, 2013). In this view, the ability to combine organization and product design pairings into innovative products can help organizations in market expansion through gaining the competitive advantages in new market (Arslanagic-Kalajdzic et al., 2017; Kozlenkova, Samaha, \& Palmatier, 2014).

We have noted that product innovation capability reflects the ability of firms to introduce new products or services in order to satisfy market needs (Alegre \& Chiva, 2008; Gault, 2018; Slater et al., 2014). Thus, we conceptualize PICs as involving novel undertaking in terms of internal and external search for new knowledge or for ways to recombine existing knowledge in exceptional ways to produce new products (or services) that deliver values for customers. Product innovation is often aimed at maintaining the sustenance of product life because products are by their nature susceptible to dramatic change as a result of unconventional market demands, consumers' preference and needs, technological change, shorter product life cycle, and increased competition. The extant studies suggest that product innovation is very crucial because it allow organizations to respond quickly to customers' needs, increase product quality and variety, and gain market share (Fritsch \& Meschede, 2001; Kuncoro \& Suriani, 2018; Nieto \& Santamaria, 2010; Panigraphy \& Pradhan, 2015; Vaona \& Pianta, 2008).

Furthermore, organizations increase their profit margins because customers are willing to pay more for new and improved products; and organizations earn monopoly rents until competitors are able to imitate the new products (Cohen \& Klepper, 1996; Fossas-Olalla, 
Minguela-Rata, Lopez-Sanchez, \& Fernandez-Menendez, 2015; Fritsch \& Meschede, 2001). Still, companies that have robust PICs would make it difficult for rivals to imitate their products thereby gaining sustainable competitive advantages (Arslanagic-Kalajdzic, Balboni, Maglajlic, \& Bortoluzzi, 2017; Hsiao \& Hsu, 2018; Woschke \& Haase, 2016). This conceptualization of PICs also takes into account that successful organization and product design pairings can emerge from either internal or external sources. For example, user-driven, user-centred, or user-led product innovations connect with the realm of market and social demand, steadily increasing as enabling computing and communication technologies improve, and increase social welfare (Baldwin \& Von Hippel, 2011). In this regards, organizations should achieve an adequate balance between internal and external architectural pairings that best fits their resource configuration and strategic objectives.

We propose that, under certain conditions, the PICs advantages allow firms to gauge which architectural pairings prosper and consequently establish how industry surplus is divided. In particular, we argue that because firm-specific advantages are perceived as a twodimensional construct, when combined with product innovation capability, it should have different influences on architectural pairings between organization and product design (Brusoni \& Prencipe, 2001; Hsiao \& Hsu, 2018; MacCormack et al., 2012; Querbes \& Frenken, 2018). Therefore, we contend that the issue of architectural pairings can be examined from dynamic capability perspective but also linked to broader area of resource-based view of firms.

Following Branzei \& Vertinsky (2006), we further define product innovation capability in terms of two dimensions: (1) the capability life-cycle stage - that is, whether de-novo capabilities emerge and develop from scratch or whether extant capabilities are crosspollinated, updated, and adjusted; and (2) the capability payoff schedule - that is, the time lag required before the operational capabilities they engender can translate into firm-level performance improvements. Theoretically, the first dimension distinguishes capability 
emergence and early development from later honing, grafting, and branching (Helfat \& Peteraf, 2003). In fact, research on PICs correspondingly differentiates between existing competencies and competencies new to the firm (Danneels, 2002). Indeed, the initial development of novel PICs depends on the quantity and quality of human capital (e.g., the knowledge, interaction, task-ability, and willingness of the team members to learn) (Branzei \& Vertinsky, 2006).

In addition, Levinthal \& Myatt (1994) found that hiring, training, improved coordination, and learning by doing facilitate capability emergence. In our context, we argue that robust organization and product design pairings emergence is facilitated by firm's investment in human capital as well as organizational learning that promote value creation. In another context, capability alterations, expansions, and refinements are normally motivated by firms' desire to transfer their extant capabilities to new markets - e.g, replication (Winter \& Szulanksi, 2001) and/or new product lines - e.g., redeployment (Helfat \& Raubitschek, 2000). Thus, we suggest that organization and product design pairings are shape by firms' willingness to transfer extant capabilities in form of architectural pairings to dominate existing market or capture new market. In turn, success depends on organizations' abilities to delink existing capabilities from the products in which they have been embodied or the markets in which they have been successfully deployed and to relink them to distinct product lines and new market niches (Branzei \& Vertinsky, 2006; Denneels, 2002).

The second dimension of product innovation capability is corollary to the first dimension, distinguishing between 'potential' and 'realised' capabilities (Zahra \& George, 2002). This research suggests that potential capabilities foster adaptability and constant competence renewal by prompting firms to scan, interpret, and incorporate fresh insights from external sources. It is essential to note that before potential capabilities can yield their expected payoffs, organizations need to surface and reconcile incongruities between internal and external information streams, overcome absorption barriers, and resolve the significant 
uncertainty often associated with 'borrowed' knowledge (Branzei \& Vertinsky, 2006; FossasOlalla et al., 2015; Gault, 2018). On the other hand, realized capabilities rely and build primarily on each firm's accumulated internal expertise. In context, when realised capabilities are abundant and fungible, they catalyse a varied range of profitable applications that can quickly translate into superior performance (Branzei \& Vertinsky, 2006; Fritsch \& Meschede, 2001; Hsiao \& Hsu, 2018).

In sum, the capability life-cycle stage and payoff schedule dimensions of product innovation capability are integral to firms' choice of organization and product design pairings. Moreover, following the capability life-cycle stage, emergent capabilities tend to mature, over time, into established capabilities whereas following the payoff schedule dimension, potential capabilities often give renewed and different ingredients which stimulate innovative recombination of firms' realized capabilities (Branzei \& Vertinsky, 2006). However, as Atuahene-Gima (2005) explains it, managers face an important strategic dilemma in product innovation: how to exploit existing product innovation competencies (competence exploitation) while avoiding their dysfunctional rigidity effects by renewing and replacing them with entirely new competencies (competence exploration). Therefore, we further propose that the influence of PICs on organization and product design pairings are evident in firm's (1) market orientation, (2) the organizational form, and (3) managerial strategic decisions that augment the architectural pairings advantages associated with organizations design products (See Figure 1 below). Next, we elaborate on these three main themes around which PICs influence organization and product design pairings.

Figure 1: Conceptualization of PICs influence on organization and product design pairings

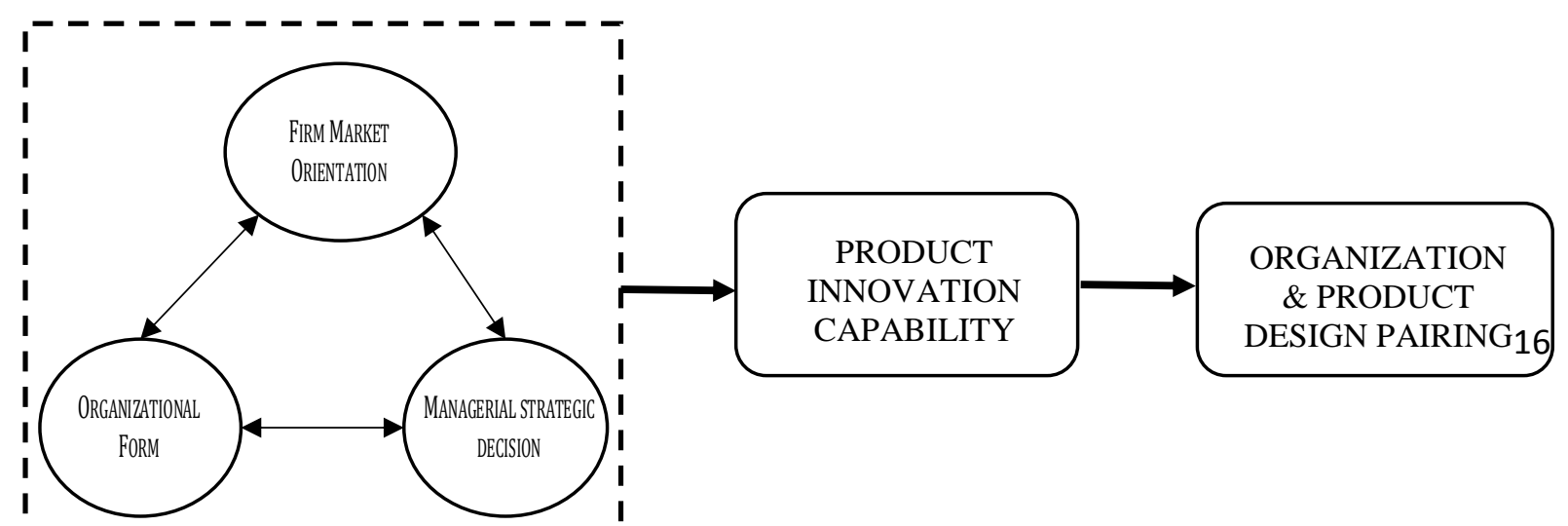




\subsection{MARKET ORIENTATION}

The extant literature has shown that PICs are a higher-order capability that facilitates the firm's internal development of requisite capabilities (e.g., architectural pairings). We distinguish that PICs are used by firms to recognize and respond to market opportunities, and threats by extending, modifying, changing, and/or creating a firm's ordinary capabilities to accomplish first-order change (Danneels, 2002; Gulbrandsen, Lambe, \& Sandvik, 2017; Winter, 2003). A PICs view would potentially address the need for a market orientation in organization and product design pairings, and thus, firms' architectural pairings decision would be more likely to reflect their market orientation. The firm's market orientation appears to be such a factor because scholars (e.g., Atuahene-Gima 2005, p. 61; Day 1994, p. 41; Hurley \& Hult 1998, p. 47) advance that market orientation is a precursor to product innovation capability building. The case of how DuPont overcame its problems in developing radical product innovation, Woolworth's renewed ability to respond to upstart rivals or competitors such as Wal-Mart, and Hewlett-Packard's leadership position in the printer business (Atuahene-Gima, 2005) appear to agree with this proposition. In each case, the organization's resource allocations to exploit existing capabilities and to develop new ones were affected substantially by its knowledge of current and future customers and competitors (Atuahene-Gima, 2005).

Unlike in the past, firms now focus on their market orientation. This shift influences organization and product design pairings (Branzei \& Vertinsky, 2006; MacCormack et al., 2012; Querbes \& Frenken, 2018) because market orientation has the potential to unlock one of the most intriguing managerial dilemmas in organization and product design pairings decision - that is, which architectural pairings should be selected, and which one would 
prosper. The market orientation view advocates intensifying effort towards customer orientation and competitor orientation during organization and product design pairings. Here, customer orientation involves generating information about current and future customers and disseminating and using it within the firm. By contrast, competitor orientation involves generating information about current and future competitors and disseminating and using it within the firm (Atuahene-Gima, 2005; Jaworski \& Kohli, 1993).

Thus, organization and product design pairings should integrate market orientation as this construct reduces safeguarding products failure costs. Market knowledge is a resource with which managers can uncover current capability deficiencies in the firm and emerging market opportunities that may require the development of new PICs (Atuahene-Gima, 2005). It follows that market orientation shape firm PICs of firm and consequently impact on organization and product design pairings and reduces safeguarding products failure costs across the board (Atuahene-Gima \& Ko, 2001; Kuncoro \& Suriani, 2018; Nieto \& Santamaria, 2010; Slater \& Narver, 1995; Slater et al., 2014; Sorescu, Chandy, \& Prabhu, 2003). The organization and product design pairings decision is of fundamental strategic importance to firms, and has been the focus of a vast amount of research inquiry in this domain (e.g., Arslanagic-Kalajdzic et al., 2017; MacCormack et al., 2012; Tsai \& Yang, 2013; Vicente et al., 2015; Querbes \& Frenken, 2018). From a marketing perspective, organization and product design pairings impact the size of markets for accompanying products (or services). Understanding the drivers of organization and product design pairings is vital to identify which parts of the value chain contribute to success of architectural pairings in the market.

Although some scholars suggest that a focus on current market conditions could lead an organization into a "competency trap" by diverting attention away from emerging customers and competitors (Atuahene-Gima, 2005). Conversely, alternative perspective claims that an awareness of changing market conditions can cause current practices (e.g., product design 
organizations) in the organization to be considered inadequate (Barnett, Greve, \& Park, 1994). Thus, an organization that faces competition is more likely to refine current routines to reflect market orientation whilst working on organization and product design pairings. In particular, market-oriented firms respond to current market conditions as well as anticipate future market conditions (Atuahene-Gima, 2005; Day, 1994; Kuncoro \& Suriani, 2018; Slater \& Narver, 1995). As we contextualize it, with deeper market knowledge, managers become dissatisfied with the inadequacies of current 'product design organizations' (i.e., mirroring) capabilities, which results in investments in new 'organizations design product' capabilities (AtuaheneGima \& Ko, 2001; Fritsch \& Meschede, 2001) and insightful strategic direction in architectural pairings (Cataldo et al., 2006; Park \& Ro, 2013).

In brief, we draw on RBV of the firm and marketing theory which suggest that the components of market orientation play a significant role in organization and product design pairings. This viewpoint implies that market orientation would allow firms to evaluate a wide range of questions including (1) are the architectural pairings completely new to the world, or modifications and second moves into the market? (2) do organization and product design pairings affect competitors in the given market or do they lead to new market creation? (3) has the value proposition for one or more customer segments changed?, and (4) has customer perception of products or of the organization changed? (cf. Prange \& Schlegelmilch, 2018). We believe that answers to these questions are crucial and potentially shape how different pairings of architectures come to emerge, survive and/or evolve.

\subsection{ORGANIZATIONAL FORM}

The organizational form is an important factor in architectural pairings emergence. In particular, organization concept describes how the differing preferences, information, knowledge and skills of these organizational actors are integrated to achieve collective action 
(MacCormack et al., 2012). One stream of research known as the classical approaches to organization concept emphasized formal structure, authority, control, and hierarchy (e.g., the division of labour and specialization of work) as distinctive features of organizations. The alternative stream of research argued that organizations are best analysed as social systems, given they comprise actors with different motives and values that do not always behave in a rational economic manner (MacCormack et al., 2012; Sosa et al., 2004; Querbes \& Frenken, 2018). This latter perspective has been extended to the link between an organization and the environment in which it operates (MacCormack et al., 2012). In this regards, organizations are seen as open systems encompassing interdependent activities linking shifting coalitions of participants (Scott, 1981).

A fundamental notion is that organizations can vary considerably in their design; the optimal design for a specific mission is established by assessing the fit between an organization and the nature of the tasks it must accomplish (MacCormack et al., 2012). The literature suggests that organizations are complex systems comprising individuals or groups that coordinate actions in pursuit of common goals, and several elements with different levels of coupling between them (Weick, 1976). Here, following Orton \& Weick (1990), we acknowledged that organizational coupling can be tightly-coupled and/or loosely-coupled. A tightly coupled organization has a set of mutually understood rules enforced by an inspection and feedback system. By contrast, in a loosely-coupled organization some of the elements of a tightly-couple organization are not in effect. Weick (1976) defined loose-coupling as a situation in which elements are responsive, but retain evidence of separateness and identity. Albeit mixed organizational structures is also a possibility in practice. The literature review reveals a consensus among scholars that different organizational forms influence organization and product design pairings. 
The extant literature found that Weick's contribution on organizational coupling is relevant to our understanding of architectural pairings emergence, survival and evolution. For example, the loose-coupling perspective suggests that any location in an organization (top, middle, or bottom) contains interdependent elements that vary in the number and strength of their interdependencies (Orton \& Weick, 1990). In our review context, studies suggested that architectural decomposition and 'mirroring' between task boundaries, knowledge boundaries, and firm boundaries are an effective way to enhance managerial efficiency and a source of potential strategic advantage (Burton \& Galvin, 2018; Querbes \& Frenken, 2018). The fundamental assumption is that organizational form (tightly-coupled or loosely-coupled) mediate a firm new product development and by extension architectural pairings. This arguably shape or influence the selection of organization and product design pairings.

Clearly, there is renewed scholarly interest on the notion of mirroring (Burton \& Galvin, 2018; Colfer \& Baldwin, 2016; Fixson \& Park, 2008; MacCormack et al., 2012; Park \& Ro, 2013; Vicente et al., 2015; Querbes \& Frenken, 2018) which predicts that it is efficient for product and organizational design to be a mirror of each other (Sanchez \& Mahoney, 1996). There is another argument that partial mirroring is effective because in complex systems with changing technologies, tasks and decisions are often more interdependent than system designers realize (Colfer \& Baldwin, 2016). This provides the premise for our view that organizational form play fundamental role in organization and product design pairings decision. Albeit one of the main critiques against the mirroring hypothesis has been that product architectures are not necessarily stable, and therefore co-evolve with organizational processes (Brusoni et al., 2001; Cabigiosu \& Camuffo, 2010; Campagnolo \& Camuffo, 2010; Furlan, Cabigiosu, \& Camuffo, 2014; Querbes \& Frenken, 2018). Therefore, we theorize that, given the organizational form, product innovation capability mediate the organization and product design pairings decision. The contextual argument is that architectural pairings are subject to 
spontaneous changes and preserve some degree of interdependence across multidimensional factors such as PICs. Furthermore, if competition is profoundly intense, firms would rely on their organizational form to provide strategic direction which can bring about wholesale changes to architectural pairings.

\subsection{MANAGERIAL STRATEGIC DECISIONS}

It has been shown that managerial attention is an important driver of product innovation regardless of whether the focus of attention is specifically on new product development, on product modification, or on the future (Yadav, Prabhu, \& Chandy, 2007). Resolving the strategic dilemma in product innovation: how to exploit existing product innovation competencies (competence exploitation) while avoiding their dysfunctional rigidity effects by renewing and replacing them with entirely new competencies (competence exploration) requires an assessment of the effects of managerial strategic decisions on architectural pairings. In context of product innovation, capabilities are said to reside within the organization's human resources, particularly managers (Penrose, 2009). Whilst there are few exceptions, the role of an organization's key individuals such as product managers and strategic managers in positions of leadership has been under-explored in the PICs perspective (Teece, 2016). Besides, Pryor, Webb, Ireland, \& Ketchen Jr (2016) have examined the roles of key organizational actors and their interactions, and how these can help form organizational capabilities comprising PICs.

The central claim is that identifying the role of strategic leaders and their interactions within the PICs is essential in that it could enable managers to understand where these "capabilities come from and what kind of investment $[\ldots]$ and managerial effort is required in building them" (Ethiraj, Kale, Krishnan, \& Singh, 2005). In fact, empirical studies have associated key individuals in firms like founders, CEOs and top managers with a central role in the dynamic capabilities view, and indeed PICs (Teece, 2016; Zahra, Sapienza, \& 
Davidsson, 2006). For example, Zahra et al. (2006) had claimed that leadership plays a fundamental role in the development of organizational dynamic capabilities. The main contention is that differences in managerial dynamic capabilities which arise from the interplay between leaders' human and social capital and their cognition would influence organizational dynamic capabilities.

Equally, research suggests that there is no guarantee that strategic leaders will often possess these positive attributes. For example, Levay (2010) found that individual charismatic leaders can also be powerful inhibitors of organizational change. They can sometimes misuse their string influence over followers to foster resistance to organizational change in situations wherein strategic change threatens their own position or influence (Van Knippenberg \& Sitkin, 2013; Mafimisebi, 2016; Mafimisebi \& Ogbonna, 2016). Furthermore, research on decision making behaviour has shown that individuals can deviate systematically from deciding rationally especially under conditions of uncertainty (Kahneman \& Tversky, 1979; Mafimisebi \& Thorne, 2015; Mafimisebi \& Thorne, 2017)). Specifically, our argument is that decision biases including the status quo bias and loss aversion (Kahneman \& Knetsch, 1991) can deter firms from seizing opportunities with respect to organization and product design pairings. For instance, the endowment effect, which denotes the tendency to overestimate the value of one's own resources, can keep an organization from renewing its resource bases even though its resources are in fact becoming inferior compared with its competitors (Pitelis \& Wagner, 2018).

Simply put, organization and product design pairings would be influence by the managerial strategic choice. Likewise, loss aversion can have a negative effect on firm's PICs, if firms are overly cautious about the risks involved in architectural pairings and therefore refrain from seizing new opportunities in the market. In context, managerial decisions also facilitate how different pairings of architectures come to emerge, survive, or evolve. More so, 
the status quo bias, which causes decision makers to discriminate against options that threaten the current status quo, can inhibit organizations' architectural pairings emergence, survival, or evolution in their changing and turbulent environment (Pitelis \& Wagner, 2018). Thus, our argument is that managerial strategic decision also impact a firm's architectural pairings emergence, survival and evolution.

\section{DISCUSSION}

This article contributes to product innovation theory and 'organizations design products' perspective in three main respects: First, the paper incorporates resource-based view of firms and market orientation theory into the organizations design products research stream that views the relationship between the organization design and the technical product it designs as running from organizational design to product design (Colfer \& Baldwin, 2016; Fixson \& Park, 2008; MacCormack et al., 2012; Park \& Ro, 2013; Vicente et al., 2015; Querbes \& Frenken, 2018). According to the products design organizations perspective, an organizational design is expected to mirror its product's design (Colfer \& Baldwin, 2016; Querbes \& Frenken, 2018), but the challenge is how to determine which architectural pairings will succeed. By addressing the link between market orientation and PICs, this article meet this challenge and presents a novel perspective of the influence of market orientation in product innovation, and by extension architectural pairings emergence, survival and evolution. In particular, the market orientation view advocates intensifying effort towards customer orientation and competitor orientation insofar as it forms the basis for organization and product design pairings decision. This evidence contributes to the product innovation theory by providing a new theoretical mechanism by which market-oriented practices are connected to organization and product design pairings. 
Second, the finding of moderating role of organizational form resonates with research that suggests the optimal design for a specific mission is established by assessing the fit between an organization and the nature of the tasks it must accomplish (MacCormack et al., 2012) and one of organizational coupling which shapes the architectural decomposition and mirroring between task boundaries, knowledge boundaries, and firm boundaries (Burton \& Galvin, 2018; Brusoni et al., 2001; Cabigiosu \& Camuffo, 2010; Campagnolo \& Camuffo, 2010; Colfer \& Baldwin, 2016; Furlan et al., 2014; MacCormack et al., 2012; Park \& Ro, 2013; Querbes \& Frenken, 2018). In addition, by acknowledging that architectural pairings are subject to spontaneous changes, firms would rely on their organizational form to ensure organization and product designs pairings emerge and survive in turbulent and dynamic market. These findings emphasize the wisdom of a pragmatic view of organizational form and suggest a more practical view of the different forms, structures and units of organization than has previously been provided in the existing literature. Third, this article advances current knowledge regarding resolving the strategic dilemma in product innovation: how to exploit existing product innovation competencies while avoiding their dysfunctional rigidity effects by renewing and replacing them with entirely new competencies. By uncovering the role of managerial strategic decisions on architectural pairings emergence and survival, this article extends the domain of analysis in modularity, mirroring and product innovation research as also involving a trade-off among managerial choice, organizational form and market orientation. Our literature review reveals that these three factors (market orientation, organizational form, and managerial strategic decisions) are essential in determining which architectural pairings will emerge and prosper. It also emphasizes the notion that organizations design products raises the prospect that PICs substantially shape architectural pairings between organisation and product designs. More critically, the argument is strengthened by recognizing that PICs lead to better selection of organization and product design pairings, unmatched 
customer benefits, better market acceptance, and significant cost reduction, and firm's ability to create new products (Atuahene-Gima \& Ko, 2001; Hsiao \& Hsu, 2018; Li et al., 2008; Slater \& Narver, 1995; Slater et al., 2014).

\section{LIMITATIONS AND FUTURE DIRECTION}

Developing a scale for measuring the effect of PICs on organization and product design pairings is constrained by at least two limitations, which also represent fertile ground for future research. First, although a conceptualization of PICs has been presented through two dimensions, further research should confirm the measurement and test its validity. This provides research opportunity to collect primary data in evaluating to what extent PICs influence organization and product design pairings. Second, albeit the article have focused on PICs, some other factors which may also influence organization and product design pairings are not considered. Therefore, it would be interesting to see future research explore what other factors might influence organization and product design pairings, other than PICs.

Nonetheless, in this article we have attempted to present a complementary view of how PICs influence organization and product design pairings. The review predicts that the influence of PICs on organization and product design pairings manifested across three main areas: market orientation, organizational form, and managerial strategic decision. These three areas further provide valuable opportunities to examine and measure how each of the construct influences organization and product design pairings. Furthermore, it opens up the opportunities to engage in debates about success factors in organization and product design pairings. Collectively, the findings offer valuable insights for future research of innovations, organization and product design pairings with significant implications for management practices. Finally, opportunities exist for future research to examine the several propositions presented in this study; offering an effective approach for improving organization and product design pairings. 
In conclusion, we began this article by noting that organizations face particularly increased difficulties in gaining sustained competitive advantage when adopting a mirroring approach to organization and product design pairings. The product innovation capability of firm is essential in resolving which architectural pairings will succeed and prosper in the market. Drawing upon the RBV of firms and market orientation theory, we expect that the influence of PICs on architectural pairings between organization and product design are driven by the firms' market orientation, organizational form, and managerial strategic decisions. Our article thus captures PICs as core to gaining sustainable advantage in organization and product design pairings. 


\section{REFERENCES}

Adams, R., Bessant, J., and Phelps, R., (2006). Innovation management measurement: a review. International Journal of Management Review 8 (1), 21-47.

Alegre, J., \& Chiva, R. (2008). Assessing the impact of organizational learning capability on product innovation performance: An empirical test. Technovation, 28, 315-326.

Ambrosini, V., \& Bowman, C. (2009). What are dynamic capabilities and are they a useful construct in strategic management? International Journal of Management Reviews, 11, $29-49$.

Andrew, J., Manget, J., Michael, D., Taylor, A., \& Zablit, H. (2010). Innovation 2010: A Return to Prominence-and the Emergence of a New World Order. BCG report. Retrieved from https://www.bcg.com/documents/file42620.pdf

Arslanagic-Kalajdzic, M., Balboni, B., Kadic-Maglajlic, S., \& Bortoluzzi, G. (2017). Product innovation capability, export scope and export experience: Quadratic and moderating effects in firms from developing countries. European Business Review, 29(6), 690-696.

Atuahene-Gima, K. (2005). Resolving the capability-rigidity paradox in new product innovation. Journal of Marketing, 69, 61-83.

Atuahene-Gima, K., \& Ko, A. (2001). An empirical investigation of the effect of market orientation and entrepreneurship orientation alignment on product innovation, Organization Science 12(1), 54-74.

Astebro, T., \& Michaela, J. L. (2005). Predictors of the survival of innovations. Journal of Product Innovation Management 22 (3), 322-335.

Baldwin, C.Y., Clark, K.B., (2000). Design Rules, Volume 1, The Power of Modularity. Cambridge, MA: MIT Press. 
Baldwin, C., \& Von Hippel, E. (2011). Modelling a paradigm shift: From producer innovation to user and open collaborative innovation. Organization Science, 22(6), 1399-1417.

Barreto, I. (2010). Dynamic capabilities: a review of past research and an agenda for the future. Journal of Management, 36, 256-280.

Barnett, W. P., Greve, H. R., \& Park, D. Y. (1994). An evolutionary model of organizational performance. Strategic Management Journal, 15, 11-28.

Balachandra, R., \& Friar, J. H. (1997). Factors for success in R\&D projects and new product innovation: A contextual framework. IEEE Transactions on Engineering Management, 44(3), 276-287.

Belenzona, S. and Patacconi, A. (2013). Innovation and firm value: an investigation of the changing role of patents, 1985-2007. Research Policy 42, 1496-1510.

Branzei, O., \& Vertinsky, I. (2006). Strategic pathways to product innovation capabilities in SMEs. Journal of Business Venturing, 21, 75-105.

Breznik, L., \& Hisrich, R. (2014). Dynamic capabilities vs. innovation capability: are they related? Journal of Small Business and Enterprise Development, 21, 368-384.

Brown, S., \& Eisenhardt, K., (1995). Product development: past research, present findings, and future directions. Academy of Management Review 20 (2), 343-378.

Brusoni, S., Prencipe, A., \& Pavitt, K., (2001). Knowledge specialization, organizational coupling and the boundaries of the firm: why do firms know more than they make? Administrative Science Quarterly 46 (4), 597-621.

Burton, N., \& Galvin, P. (2018). When do product architectures mirror organisational architectures? The combined role of product complexity and the rate of technological change. Technology Analysis and Strategic Management, 30(2), 1-13. 
Cabigiosu, A., \& Camuffo, A. (2012). Beyond the 'mirroring' hypothesis: product modularity and interorganizational relations in the air conditioning industry. Organization Science 23, 686-703.

Campagnolo, D., \& Camuffo, A. (2010). The concept of modularity in management studies: a literature review. International Journal of Management Review 12, 259-283.

Cataldo, M., Wagstrom, P.A., Herbsleb, J.D., Carley, K.M., 2006. Identification of coordination requirements: implications for the design of collaboration and awareness tools. In: Proceedings of the ACM Conference on Computer-Supported Work, Banff, Canada, pp. 353-362.

Chen, C. (2007). Information technology, organizational structure, and new product development: The mediating effect of cross-functional interaction. IEEE Transactions on Engineering Management, 54, 687-698.

Cheng, C., \& Chen, J. (2013). Breakthrough innovation: The roles of dynamic innovation capabilities and open innovation activities. Journal of Business and Industrial Marketing, 28(5), 444-454.

Cooper, R.G. (1981). An empirically derived new product project selection model. IEEE Transactions on Engineering Management 28 (3), 54-61.

Cooper, R.G., (1999). From experience: the invisible success factors in product innovation. Journal of Product Innovation Management 16 (2), 115-133.

Colfer, L. J., \& Baldwin, C. Y. (2016). The mirroring hypothesis: theory, evidence, and exceptions. Industrial and Corporate Change, 25(5), 709-738.

Danneels, E., (2002). The dynamics of product innovation and firm competencies. Strategic Management Journal 23, 1095-1121. 
Damanpour, F., (2010). An integration of research findings of effects of firm size and market competition on product and process innovations. British Journal of Management 21, 996-1010.

Day, G. S. (1994). The capabilities of market-driven organizations. Journal of Marketing, 58, $37-52$.

Dewangan, V., \& Godse, M. (2014). Towards a holistic enterprise innovation performance measurement system. Technovation 34 (9), 536-545.

Duhamel, F., \& Santi, M. (2012). Degree of innovativeness and new product performance. Technological Analysis and Strategic Management 24 (3), 253-266.

Gulbrandsen, B., Lambe, C. J., \& Sandvik, K. (2017). Firm boundaries and transaction costs: The complementary role of capabilities. Journal of Business Research, 78, 193-203.

Edwards-Schachter, M. (2018). The nature and variety of innovation. International Journal of Innovation Studies, 2, 65-79.

Ethiraj, S. K., Kale, P., Krishnan, M. S., \& Singh, J. V. (2005). Where do capabilities come from and how do they matter? A study in the software services industry. Strategic Management Journal, 26(1), 25-45.

Eisenhardt, K.M., Martin, J.A., (2000). Dynamic capabilities: what are they? Strategic Management Journal 21, 1105-1121.

Feiler, P., Teece, D., 2014. Case study, dynamic capabilities and upstream strategy: supermajor EXP. Energy Strategy Rev. 3, 14-20.

Fixson, S. K., \& Park, J. K. (2008). The power of integrality: Linkages between product architecture, innovation, and industry structure. Research Policy, 37(8), 1296-1316. 
Fossas-Olalla, M., Minguela-Rata, B., Lopez-Sanchez, J., \& Fernandez-Menendez, J. (2015). Product innovation: When should suppliers begin to collaborate? Journal of Business Research, 68, 1404-1406.

Fritsch, M., \& Meschede, M. (2001). Product innovation, process innovation, and size. Review of Industrial Organization, 19(3), 335-350.

Furlan, A., Cabigiosu, A., Camuffo, A., 2014. When the mirror gets misted up: modularity and technological change. Strategic Management Journal 35, 789-807.

Gault, F. (2018). Defining and measuring innovation in all sectors of the economy. Research Policy, 47(3), 617-622.

Grant, R.M., (1996). Toward a knowledge-based theory of the firm. Strategic Management Journal 17(S2), 109-122.

Griffin, A., \& Page, A.L., (1993). An interim report on measuring product development success and failure. Journal of Product Innovation Management 10, 291-308.

Hansen, M. T., \& Birkinshaw, J. (2007). The innovation chain value. Harvard Business Review, 85(6), 121-130.

Helfat, C.E. (1997). Know-how and asset complementarity and dynamic capability accumulation: the case of R\&D. Strategic Management Journal, 18, 339-360.

Helfat, C.E., \& Raubitschek, R. S. (2000). Product sequencing: co-evolution of knowledge, capabilities and products. Strategic Management Journal 21(10-11), 961-980.

Helfat, C., Finkelstein, S., Mitchell,W., Peteraf, M.A., Singh, H., \& Teece, D.J. (2007). Dynamic capabilities: Understanding strategic change in organizations. Oxford: Blackwell. 
Helfat, C.E., \& Peteraf, M.A. (2003). The dynamic resource-based view: Capability lifecycles. Strategic Management Journal, 24(10), 997-1010.

Helfat, C.E., \& Winter, S.G. (2011). Untangling dynamic and operational capabilities: Strategy for the (N)ever-changing world. Strategic Management Journal, 32(11), 1243-1250.

Henderson, R.M., \& Clark, K.B. (1990). Architectural innovation: The reconfiguration of existing product technologies and the failure of established. Firms. Administrative Science Quarterly, 35(1), 9-30.

Hertog, P., Aa, W., \& Jong, M. (2010). Capabilities for managing service innovation: Towards a conceptual framework. Journal of Service Management, 21(4), 490-514.

Hsiao, Y., \& Hsu, Z. (2018). Firm-specific advantages-product innovation capability complementarities and innovation success: A core competency approach. Technology in Society, 55, 78-84.

Hurley, R. F., \& Hult, T. M. (1998). Innovation, market orientation, and organizational learning: An integration and empirical examination. Journal of Marketing, 62, 42-54.

Jaworski, B. J., \& Kohli, A. K. (1993). Market orientation: Antecedents and consequences. Journal of Marketing, 57, 53-70.

Kahneman, D., \& Knetsch, J. L. (1991). The endowment effect, loss aversion, and status quo bias. Journal of Economic Perspectives, 5(1), 193-206.

Kahneman, D., \& Tversky, A. (1979). Prospect theory: An analysis of decision under risk. Econometrica, 47(2), 263-291.

Katila, R., \& Ahuja, G. (2002). Something old, something new: a longitudinal study of search behavior and new product introduction. Academic Management Review 45(6), 11831194. 
Kindstrom, D., Kowalkowski, C., \& Sandberg, E. (2013). Enabling service innovation: A dynamic capabilities approach. Journal of Business Research, 66, 1063-1073.

Kogut, B., \& Zander, U. (1992). Knowledge of the enterprise, combinative capabilities and the replication of technology. Organizational Science, 3(3), 383-397.

Kozlenkova, I. V., Samaha, S. A., \& Palmatier, R. W. (2014). Resource-based theory in marketing. Journal of the Academy of Marketing Science, 42(1), 1-21.

Kuncoro, W., \& Suriani, W. O. (2018). Achieving competitive advantage through product innovation and market driving. Asia Pacific Management Review, 23, 186-192.

Lambertini, L., \& Mantovani, A. (2009). Process and product innovation by a multiproduct monopolist: A dynamic approach. International Journal of Industrial Organization, 27(4), 508-518.

Laursen, K., (2012). Keep searching and you'll find: what do we know about variety creation through firms' search activities for innovation? Industrial and Corporate Change 25.

Laursen, K., \& Salter, A.J., (2006). Open for innovation: the role of openness in explaining innovation performance among UK manufacturing firms. Strat. Manag. J. 27 (2), 131150.

Leiponen, A., Helfat, C.E., (2010). Innovation objectives, knowledge sources, and the benefits of breadth. Strategic Management Journal 31(2), 224-236.

Levinthal, D., Myatt, J., (1994). Co-evolution of capabilities and industry: the evolution of mutual fund processing. Strategic Management Journal 15, 45- 62.

Levay, C. (2010). Charismatic leadership in resistance to change. The Leadership Quarterly, 21(1), 127-143. 
Li, Q., Maggitti, P., Smith, K., Tesluk, P., \& Katila, R. (2013). Top management attention to innovation: the role of search selection and intensity in new product introductions. Academy of Management Journal 56(3), 893-916.

Li, Z., \& Ni, J. (2018). Dynamic product innovation and product decisions under quality authorization. Computers \& Industrial Engineering, 116, 13-21.

Li, Y., Zhao, Y., Tan, J., \& Liu, Y. (2008). Moderating effects of entrepreneurial orientation on market orientation-performance linkage: evidence from Chinese small firms, Journal of Small Business Management 46 (1), 113-133.

Lin, H., Su, J., \& Higgins, A. (2016). How dynamic capabilities affect adoption of management innovations. Journal of Business Research, 69, 862-876.

MacCormack, A., Baldwin, C., Rusnak, J. (2012). Exploring the duality between product and organizational architectures: A test of the "mirroring" hypothesis. Research Policy, 41, $1309-1324$.

Mafimisebi, O.P. (2016). Project management practice: lessons learned from project failures in Nigeria. European Journal of Business and Management 8(1) (2016) 105-118.

Mafimisebi, O.P., \& Nkwunonwo, U.C. (2015). Environmental risk: exploring organizational resilience and robustness, International Journal of Scientific \& Engineering Research 6(1), 1103-1115.

Mafimisebi, O.P., \& Ogbonna, O.C. (2016). Environmental risk of gas flaring in Nigeria: lessons from Chevron Nigeria and Ilaje crisis. Journal of Economics and Sustainable Development 7(1), 180-204. 
Mafimisebi, O.P., \& Thorne, S. (2015). Oil terrorism-militancy link: mediating role of moral disengagement in emergency and crisis management, Journal of Emergency Management 13(5), 447-58.

Mafimisebi, O.P., \& Thorne, S. (2017). Vandalism-militancy relationship: The influence of risk perception and moral disengagement, International Journal of Mass Emergencies and Disasters 35(3), 191-223.

Makkonen, H., Pohjola, M., Olkkonen, R., \& Koponen, A. (2014). Dynamic capabilities and firm performance in a financial crisis. Journal of Business Research, 67, 2707-2719.

Martins, L.L., Rindova, V.P., \& Greenbaum, B.E., (2015). Unlocking the hidden value of concepts: a cognitive approach to business model innovation. Strategic Entrepreneurship Journal 9 (1), 99-117.

Mousavi, S., \& Bossink, B. A. G. (2017). Firms' capabilities for sustainable innovation: The case of biofuel for aviation. Journal of Cleaner Production, 167, 1263-1275.

Nieto, M. J., \& Santamaría, L. (2010). Technological collaboration: Bridging the innovation gap between small and large firms. Journal of Small Business Management, 48(1), 4469.

Orton, J.D., Weick, K.E., (1990). Loosely-coupled systems: a reconceptualization. Academy of Management Review 15, 203-223.

Pan, X. J., \& Li, S. D. (2016). Dynamic optimal control of process-product innovation with learning by doing. European Journal of Operational Research, 248, 136-145.

Park, J., \& Ro, Y. K. (2013). Product architectures and sourcing decisions. Their impact on performance. Journal of Management, 39(3), 814-846. 
Panigrahy, P. N., \& Pradhan, K. R. (2015). Creativity and innovation: Exploring the role of HR practices at workplace. Presentation of Paper at National Conference organized by Ravenshaw B-School, Cuttack.

Patel, P., Pavitt, K., (1997). The technological competencies of the world's largest firms: complex and path-dependent, but not much variety. Research Policy 26 (2), 141-156.

Penrose, E. T. (2009). The theory of the growth of the firm (4th ed.). Oxford: Oxford University Press.

Pil, F. K., \& Cohen, S. K. (2006). Modularity: Implications for imitation, innovation, and sustained advantage. Academy of Management Review, 31(4), 995-1011.

Pitelis, C. N., \& Wagner, J. D. (2018). Strategic shared leadership and organisational dynamic capabilities. The Leadership Quarterly. Retrieved from https://doi.org/10.1016/j.leaqua.2018.08.002

Prange, C., \& Schlegelmilch, B. B. (2018). Managing innovation dilemmas: The cube solution. Business Horizon, 61, 309-322.

Pryor, C., Webb, J. W., Ireland, R. D., \& Ketchen, D. J., Jr. (2016). Toward an integration of the behavioral and cognitive influences on the entrepreneurship process. Strategic Entrepreneurship Journal, 10, 21-42.

Querbes, A., \& Frenken, K. (2018). Grounding the "mirroring hypothesis": Towards a general theory of organization design in new product development. Journal of Engineering and Technology Management, 47, 81-95.

Rothaermel, F. T., \& Hess, A. M. (2007). Building dynamic capabilities: innovation driven by individual-, firm-, and network-level effects. Organization Science, 18, 898-921. 
Saha, S. (2007). Consumer preferences and product and process R\&D. RAND Journal of Economics, 38(1), 250-268.

Sanchez, R., \& Mahoney, J. T. (1996). Modularity, flexibility, and knowledge management in product and organization design. Strategic Management Journal, 17, 63-76.

Schaefer, S. (1999). Product design partitions with complementary components. Journal of Economic Behaviour \& Organization, 38, 311-330.

Schilling, M.A., 2000. Toward a general systems theory and its application to interfirm product modularity. Academy of Management Review 25 (2), 312-334.

Scott, W.R., 1981. Organizations: Rational, Natural and Open Systems. Prentice-Hall, Inc., New Jersey.

Shibata, T. (2009). Product innovation through module dynamics: A case study. Journal of Engineering Technology Management, 26, 46-56.

Slater, S. F., Mohr, J. J., \& Sengupta, S. (2014). Radical product innovation capability: Literature review, synthesis, and illustrative research propositions. Journal of Product Innovation Management, 31(3), 552-566.

Slater, S. F., \& Narver, J.C. (1995). Market orientation and the learning organization, Journal of Marketing 59 (3) (1995) 63-74.

Slater, S. F., Mohr, J. J., \& Sengupta, S. (2014). Radical product innovation capability: Literature review, synthesis, and illustrative research propositions. Journal of Product Innovation Management, 31, 552-566.

Sosa, M., Eppinger, S., \& Rowles, C., (2004). The misalignment of product architecture and organizational structure in complex product development. Management Science 50 (December), 1674-1689. 
Snihur, Y., \& Wiklund, J. (2018). Searching for innovation: Product, process, and business model innovations and search behaviour in established firms. Long Range Planning, 121. Retrieved from https://doi.org/10.1016/j.lrp.2018.05.003

Stuart, T.E., Podolny, J.M., 1996. Local search and the evolution of technological capabilities. Strategic Management Journal 17(S1), 21-38.

Teece, D. J. (2007). Explicating dynamic capabilities: the nature and microfoundations of (sustainable) enterprise performance. Strategic Management Journal, 28, 1319-1350.

Teece, D. J., Pisano, G., \& Shuen, A. (1997). Dynamic capabilities and strategic management. Strategic Management Journal, 18, 509-533.

Tsai, K. H., \& Yang, S. Y. (2013). Firm innovativeness and business performance: the joint moderating effects of market turbulence and competition. Industrial Marketing Management, 42(8), 1279-1294.

Ulrich, K. (1995). The role of product architecture in the manufacturing firm. Research Policy 24, 419-440.

Van Knippenberg, D., \& Sitkin, S. B. (2013). A critical assessment of charismatictransformational leadership research: Back to the drawing board? The Academy of Management Annals, 7(1), 1-60.

Vaona, A., \& Pianta,M. (2008). Firmsize and innovation in European manufacturing. Small Business Economics, 30(3), 283-299.

Vicente, M., Abrantes, J. L., \& Teixeira, M. S. (2015). Measuring innovation capability in exporting firms: the INNOVSCALE. International Marketing Review, 32, $29-51$.

Von Hippel, E. (2005). Democratizing innovation. USA: The MIT Press. 
Wang, C. L., \& Ahmed, P. K. (2004). The development and validation of the organisational innovativeness construct using confirmatory factor analysis. European Journal of Innovation Management, 7, 303-313.

Wang, C., \& Ahmed, P. (2007). Dynamic capabilities: A review and research agenda. International Journal of Management Reviews, 9(1), 31-51.

Winter, S.G., \& Szulanski, G. (2001). Replication on strategy. Organization Science 12(6), $730-743$.

Winter, S. G. (2000). The satisficing principle in capability learning. Strategic Management Journal, 21(10/11), 981-996.

Winter, S. G. (2003). Understanding dynamic capabilities. Strategic Management Journal, 24(10), 991-995.

Woschke, T., \& Haase, H. (2016). Enhancing new product development capabilities of small and medium sized enterprises through managerial innovations. Journal of High Technology Management Research 27, 53-64.

Wu, Q., He, Q.L., Duan, Y.Q., \& O'Regan, N. (2012). Implementing dynamic capabilities for corporate strategic change toward sustainability. Strategic Change, 21(5-6), 231-247.

Xie, X., Fang, L., Zeng, S., \& Huo, J. (2016). How does knowledge inertia affect firms product innovation? Journal of Business Research, 69, 1615-1620.

Yadav, M., Prabhu, J., \& Chandy, R. (2007). Managing the future: CEO attention and innovation outcomes. Journal of Marketing, 71(4), 84-101.

Zahra, S.A., George, G., 2002. Absorptive capacity: a review, reconceptualization, and extension. Academy Management Review 27(2), 185- 203. 
Zahra, S. A., Sapienza, H. J., \& Davidsson, P. (2006). Entrepreneurship and dynamic capabilities: A review, model and research agenda. Journal of Management Studies, 43(4), 917-955.

Zahra, S. A., Sapienza, H. J., \& Davidsson, P. (2006). Entrepreneurship and dynamic capabilities: A review, model and research agenda. Journal of Management Studies, 43(4), 917-955 